\title{
Antimicrobial peptide melittin against Xanthomonas oryzae pv. oryzae, the bacterial leaf blight pathogen in rice
}

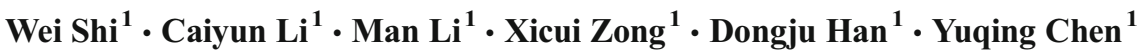

Received: 10 November 2015 /Revised: 12 February 2016/Accepted: 16 February 2016/Published online: 7 March 2016

(C) The Author(s) 2016. This article is published with open access at Springerlink.com

\begin{abstract}
Xanthomonas oryzae pv. oryzae is a destructive bacterial disease of rice, and the development of an environmentally safe bactericide is urgently needed. Antimicrobial peptides, as antibacterial sources, may play important roles in bactericide development. In the present study, we found that the antimicrobial peptide melittin had the desired antibacterial activity against $X$. oryzae pv. oryzae. The antibacterial mechanism was investigated by examining its effects on cell membranes, energy metabolism, and nucleic acid, and protein synthesis. The antibacterial effects arose from its ability to interact with the bacterial cell wall and disrupt the cytoplasmic membrane by making holes and channels, resulting in the leakage of the cytoplasmic content. Additionally, melittin is able to permeabilize bacterial membranes and reach the cytoplasm, indicating that there are multiple mechanisms of antimicrobial action. DNA/RNA binding assay suggests that melittin may inhibit macromolecular biosynthesis by binding intracellular targets, such as DNA or RNA, and that those two modes eventually lead to bacterial cell death. Melittin can inhibit $X$. oryzae pv. oryzae from spreading, alleviating the disease symptoms, which indicated that melittin may have potential applications in plant protection.
\end{abstract}

Keywords Melittin $\cdot$ Xanthomonas oryzae pv. oryzae $\cdot$ Rice

Yuqing Chen

yuqingchen515@yahoo.com

1 Jiangsu Province Key Laboratory for Molecular and Medical Biotechnology, Life Sciences College, Nanjing Normal University, Nanjing 210023, China

\section{Introduction}

Bacterial leaf blight of rice caused by Xanthomonas oryzae pv. oryzae is a destructive bacterial disease of rice in growing regions worldwide. As Gram-negative bacterium, this plant pathogen can cause vascular disease by producing yellow green spots on the leaf tips and edges, resulting in gray to white lesions along the leaf veins, which severely reduces the rice quality. The disease incidence ranges from 70 to $80 \%$, leading to significant crop damage (Basso et al. 2011; Lee et al. 2005). Currently, control relies mainly on chemical pesticides. However, their effects on long-term environmental pollution and carcinogenic effects on humans and other animals limit their future use (Daoubi et al. 2005). Thus, to develop new antimicrobial resources with reduced negative environmental impacts is urgently needed to replace the traditional synthetic chemical pesticides used in plant protection.

Antimicrobial peptides (AMPs) are important host defense molecules involved in innate immunity. To date, almost 2100 peptides with antibacterial activity had been discovered from different species (http://aps.unmc.edu/AP/). They are small ( $\sim 10-50$ residues), generally amphipathic molecules, and most of them contain cationic and hydrophobic residues in elevated proportions. Natural AMPs exhibited a broad activity to directly kill bacteria, yeasts, fungi, viruses, parasites, and even cancer cells. These activities are diverse, specific to the type of AMPs (Zhang and Gallo 2016). The use of AMPs as novel antibiotics in medical application has been proposed and widely accepted for a long time. Although there are the numerous models to explain their mechanism of action ranging from pore formation to general membrane disruption, in fact, it is a complicated interaction between different AMPs and different microbial membranes, which govern membrane selectivity of AMPs (Lee et al. 2016). Besides the use in medical application, AMPs have possible roles as agriculture 
pesticides for plant disease control because of their short sequences, broad antimicrobial spectra, and diverse sources (Montesinos 2007). Moreover, their mode of action, mainly targeting the microbial cell membrane directly, is thought to reduce the risk of resistance development in microbial population. AMPs have been reported as candidates for plant protection against bacterial and fungal pathogens. Until now, several natural AMPs, such as cecropin (silkmoth) and some modified AMPs, were reported in vitro and ex vivo (detected leaves or fruits) against plant pathogens (Alan and Earle 2002; Coca et al. 2006; Zeitler et al. 2013). However, almost no effective AMPs have been reported against $X$. oryzae pv. oryzae, the most important bacterial pathogen.

Melittin, the main component of European honeybee venom from Apis mellifera, is a cationic peptide $(+5$ net charge) composed of 26 amino acid residues (GIGAVLKVLTTGLPALISWIKRKRQQ). Melittin has diverse activities, including antibacterial, antifungal, antiviral, anticancer, and anti-inflammatory, as well as wound-healing potential (Alia et al. 2013; Falco et al. 2013; Park and Lee 2010). It has membrane activity as well as the ability to form pores across the lipid bilayer (Lee et al. 2013). Several studies demonstrated that mellitin exhibits a broad-spectrum antibacterial activity and is more active against Gram-positive than Gramnegative bacteria (Al-Ani et al. 2015). A tremendous amount of work has been done on antibacterial activity of melittin against human and animal pathogenic bacteria (Asthana et al. 2004; Liu et al. 2013). However, very little is known about the ability of natural melittin to act against plant pathogens, and specifically $X$. oryzae pv. oryzae. The objective of the present study is to determine the antibacterial activity of melittin against $X$. oryzae pv. oryzae and assess its protective effect against rice leaf blight.

\section{Materials and methods}

\section{Bacterial strains, peptide synthesis, and reagents}

X. oryzae pv. oryzae strain ZJ-173 (which is commonly used in China) was used in this study. X. oryzae pv. oryzae was grown at $28{ }^{\circ} \mathrm{C}$ in nutrient broth (NB) medium as described previously(Zhu et al. 2013). Melittin was synthesized using solid-phase methodology at GL Biochemistry Corporation (Shanghai, China). Preparative reverse phase highperformance liquid chromatography (RP-HPLC) resulted in final products deemed $>95 \%$ pure. Selective N-terminal fluorescein labeling of the peptide was performed with fluorescein isothiocyanate (FITC) and deemed $>95 \%$ homogeneous. 4,6diamidino-2-phenylindole (DAPI) was purchased from Sigma-Aldrich (St. Louis, MO, USA). The restriction enzymes and DNA extraction kit were purchased from Takara Bio, Inc. (Shiga, Japan), and the TransZol ${ }^{\mathrm{TM}}$ UP Plus RNA Kit was purchased from TransGen Biotech Co., Ltd. (Beijing, China). The T-ATPase (total quantity of adenosine triphosphate in the cell) and protein assay kit were purchased from Jiancheng Bioengineering Institute (Nanjing, China). All other reagents and solvents were made in China and were of analytical grade.

\section{Antibacterial activity assay}

$X$. oryzae pv. oryzae was prepared for $24 \mathrm{~h}$ in NB medium at $28{ }^{\circ} \mathrm{C}$ to achieve an inoculum of approximate mid-log phase $\left(\mathrm{OD}_{600} \sim 0.5\right)$. The antibacterial activity was tested using an agar well diffusion assay and a time-to-kill curve assay. For the former, the samples were placed in the wells of a thin agar plate seeded with $X$. oryzae pv. oryzae. Bacterial inhibition zones were detected after incubating at $28^{\circ} \mathrm{C}$ for 2 days. For the latter, bacteria cultures were treated with different concentrations of melittin. The half maximal inhibitory concentration (IC50) and microbial growth were assessed by measuring the $\mathrm{OD}_{600}$ after incubation for different concentrations $(2.5,5$, $7.5,10,20 \mu \mathrm{M})$ and different hours $(2.5,5,7.5$, and $10 \mathrm{~h})$ at $28^{\circ} \mathrm{C}$ as reported elsewhere (Tripathi et al. 2015).

\section{Determination of the DNA and RNA contents}

The determinations of DNA and RNA contents were performed using DAPI. Bacteria were incubated with melittin with final concentration of $10 \mu \mathrm{M}$ for $2.5,5$, and $7.5 \mathrm{~h}$. Phosphate-buffered saline (PBS) was used as a control. The cells were then collected and diluted with distilled water. A triple volume of DAPI was added to the resuspended bacteria. The cell samples were placed in the dark for $10 \mathrm{~min}$. The DAPI fluorescence of cells was observed using fluorescence spectrometry (364 nm for DNA and $400 \mathrm{~nm}$ for RNA). Each experiment was repeated three times.

\section{Scanning electron microscopy (SEM)}

After incubation with $10 \mu \mathrm{M}$ melittin for $30 \mathrm{~min}$ at $28{ }^{\circ} \mathrm{C}$, $X$. oryzae pv. oryzae was collected by centrifugation at 10 , $000 \times g$ for $10 \mathrm{~min}$. After washing three times with PBS, $X$. oryzae pv. oryzae was fixed with $4 \%(v / v)$ glutaraldehyde in PBS at $4{ }^{\circ} \mathrm{C}$ for $3 \mathrm{~h}$. After washing three times with the same buffer, the samples were dehydrated separately for 15 min using a graded series of ethanol solutions $(50,70$, $80,90,95$, and $100 \%(v / v))$. They were then air dried and sputter coated with gold to avoid charging effects in the microscope. Samples were viewed using a scanning electron microscope at $10 \mathrm{KV}$. 


\section{Transmission electron microscopy (TEM)}

After incubation with $10 \mu \mathrm{M}$ melittin for $30 \mathrm{~min}$ at $28^{\circ} \mathrm{C}$, $X$. oryzae pv. oryzae was collected by centrifugation at 10 , $000 \times g$ for $10 \mathrm{~min}$. After washing three times with PBS, $X$. oryzae pv. oryzae was fixed with $4 \%(v / v)$ glutaraldehyde in PBS at $4{ }^{\circ} \mathrm{C}$ for $3 \mathrm{~h}$ and then post-fixed with $1 \%$ osmium tetroxide at $4{ }^{\circ} \mathrm{C}$ for another $2 \mathrm{~h}$. After washing three times with PBS, samples were dehydrated separately for $15 \mathrm{~min}$ using a graded series of acetone solutions $(30,50,70,80$, 90 , and $100 \%$ ) and embedded in resin. The samples were cut into semi-thin sections, prepared on copper grids, and stained with uranyl acetate and lead citrate. Samples were viewed using a transmission electron microscopy system.

\section{Determination of intracellular ATP depletion}

$X$. oryzae pv. oryzae was incubated with melittin $(10,20 \mu \mathrm{M})$ for $30 \mathrm{~min}$ at $28^{\circ} \mathrm{C}$, with PBS as a control. Then, $1 \mathrm{ml}$ of each culture was centrifuged at $12,000 \times \mathrm{g}$ for $10 \mathrm{~min}$ and resuspended in $200 \mu \mathrm{l} 0.9 \% \mathrm{NaCl}$ solution. The bacteria were disrupted by sonication, and Coomassie brilliant blue R-250 (Beijing Dingguo Biotech Co. Ltd. China) was used to determine the protein content. The T-ATPase level was determined using a commercial assay kit according to the manufacturer's recommendations. T-ATPase concentrations were expressed in $\mathrm{U} / \mathrm{mg}$ protein.

\section{Confocal laser scanning microscopy}

$X$. oryzae pv. oryzae was incubated with FITC-labeled melittin $(10 \mu \mathrm{M})$ for $30 \mathrm{~min}$ in the dark at $28^{\circ} \mathrm{C}$, with PBS treatment as a control. Then, the samples were centrifuged at $5000 \times g$ for $5 \mathrm{~min}$. The bacterial pellets were washed three times with PBS. Images were collected using a confocal laser scanning microscope (excitation, $488 \mathrm{~nm}$; emission, $522 \mathrm{~nm}$ for the FITC signal).

\section{DNA/RNA gel retardation assay}

The DNA of $X$. oryzae pv. oryzae was purified using a DNA extraction kit (TransGen Biotech, Beijing). Total RNA was prepared using the TransZol UP Plus RNA Kit (TransGen Biotech, Beijing) and resuspended in diethyl pyrocarbonate (DEPC)-treated water. Gel retardation experiments were performed as described by Park et al. (1998). Briefly, mixed $200 \mathrm{ng}$ of DNA with different amounts of melittin $(10,100$, $200,400,600 \mathrm{ng}$ ) in $20 \mu \mathrm{l}$ of binding buffer ( $5 \%$ glycerol, $10 \mathrm{mM}$ Tris-HCl (pH 8.0), 1 mM EDTA (ethylenediaminetetraacetic acid), $1 \mathrm{mM} \mathrm{DL}$-dithiothreitol, $20 \mathrm{mM} \mathrm{KCl}$, and $50 \mu \mathrm{g} / \mathrm{ml}$ albumin). For RNA binding, an assay was conducted by mixing $300 \mathrm{ng}$ of RNA with melittin $(180,360,900 \mathrm{ng})$ in $30 \mu \mathrm{l}$ of binding buffer. The reaction mixtures were incubated for $1 \mathrm{~h}$ at room temperature and then subjected to gel electrophoresis on a $1 \%$ agarose gel. In addition, samples with peptide/DNA weight ratios of 0.5 were dissolved in $0.5 \mu \mathrm{l}$ Tris- $\mathrm{HCl}$ and then digested with $1 \mu \mathrm{l}$ HindIII, KpnI, $\mathrm{SacI}$, or EcoRI-HF (Takara Biotech). After incubating at $37^{\circ} \mathrm{C}$ for $3 \mathrm{~h}$, the samples were loaded on to a $1 \%$ agarose gel.

\section{Sodium dodecyl sulfate polyacrylamide gel electrophoresis (SDS-PAGE) analysis}

$X$. oryzae pv. oryzae were prepared in NB medium at $28^{\circ} \mathrm{C}$ to achieve an inoculum of approximate mid-log phase $\left(\mathrm{OD}_{600}\right.$ $\sim 0.5$ ). Then, melittin, at final concentrations of 5 and $10 \mu \mathrm{M}$, was added and cultured in a rotary shaker $(220 \mathrm{rpm})$ at $28^{\circ} \mathrm{C}$. After $5 \mathrm{~h}$, cells were collected and then an SDS-PAGE analysis was performed using $12 \%$ polyacrylamide gels. Gels were stained with Coomassie brilliant blue R-250.

\section{Disease protection studies}

The seeds from the next generation of LYP9 rice, paternal line 9311 (Oryza sativa L. ssp. indica) were sprouted after sterilization in distilled water at $28^{\circ} \mathrm{C}$ for 3 days, then planted into Kimura B nutrient solution (Ma et al. 2001), and trained to the three- or four-leaf stage in an illuminated incubator. The plants were treated with $50-100 \mu \mathrm{l}(1 \mathrm{mM} / \mathrm{ml})$ melittin by injecting the leaf stem or spraying and then placed in a $28{ }^{\circ} \mathrm{C}$ light incubator for one night. Rice leaves were inoculated using the scissor-clipping method (Burdman et al. 2004) with a bacterial suspension having an $\mathrm{OD}_{600}=0.6$. Plants without melittin and bacterial treatments were used as controls. Average lengths were measured 1 week after $X$. oryzae pv. oryzae inoculation. The experiment was performed in three replicates.

\section{Statistical analysis}

All experiments were repeated at least three times. Results are expressed as mean values \pm standard errors (mean \pm SE). The significance of the differences between the treatments and the respective controls were determined based on Student's $t$ test. A level of $P<0.05$ was considered to be significant.

\section{Results}

\section{Melittin showed antibacterial activity against $X$. oryzae pv. oryzae}

An inhibition zone assay was conducted to detect whether melittin showed antibacterial activity against $X$. oryzae pv. oryzae (Fig. 1a). Results showed that melittin has antibacterial activity to the plant pathogen at a concentration of $10 \mu \mathrm{M}$. The 
Fig. 1 Antibacterial activity of melittin against $X$. oryzae pv. oryzae. Agar well assay (a), timeto-kill curve assay (b), and the determination of DNA (c) and RNA (d) contents were conducted to detect antibacterial activity

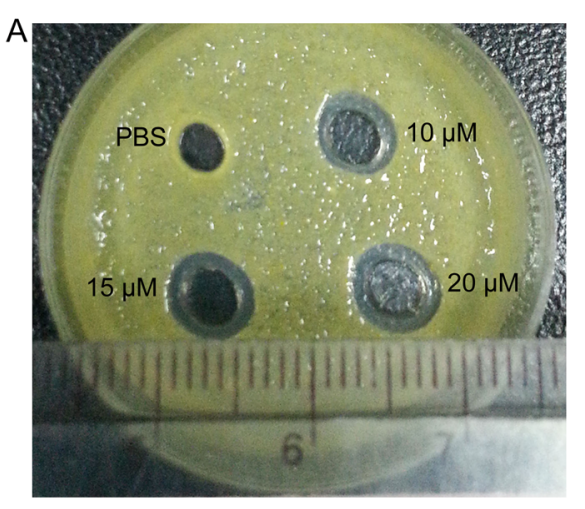

B
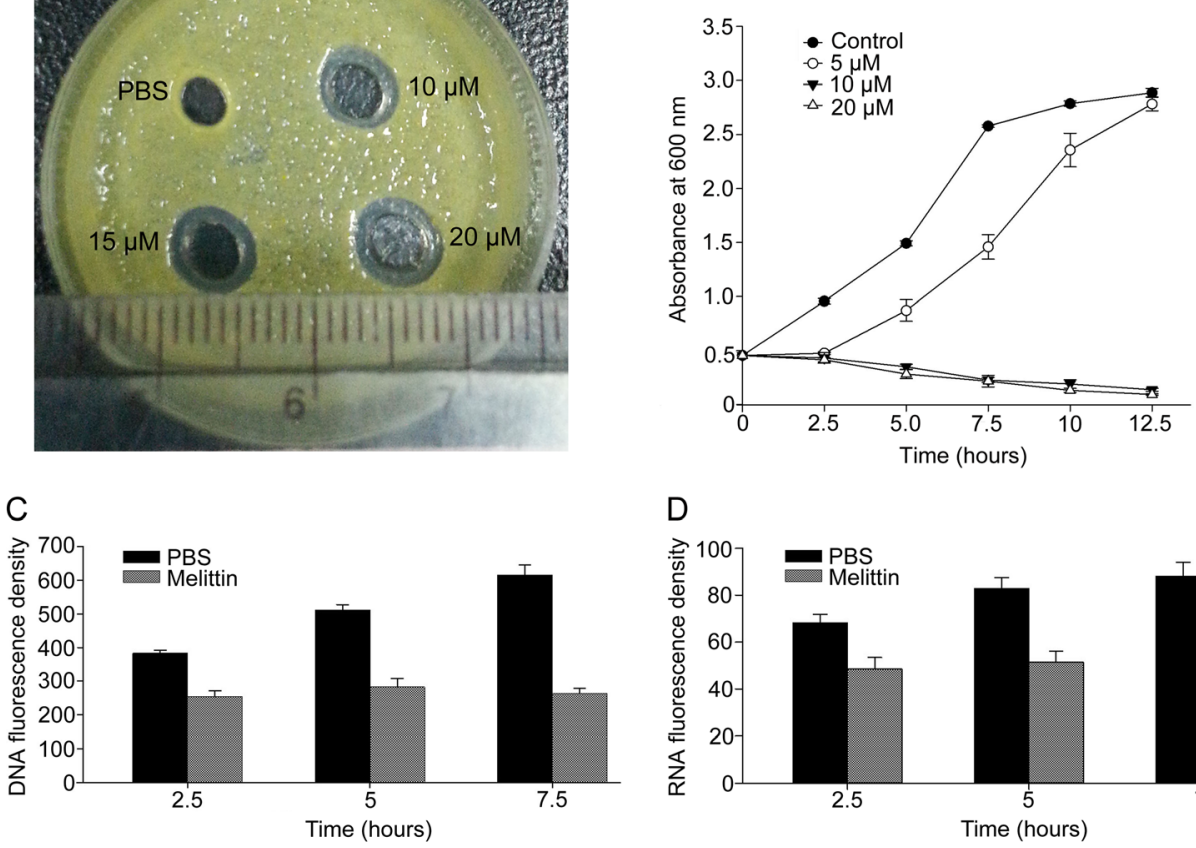

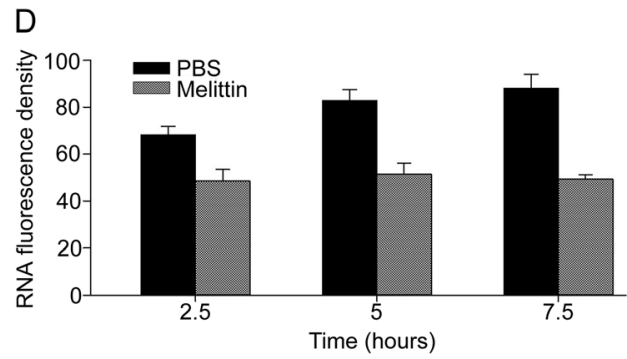

half maximal inhibitory concentration $\left(\mathrm{IC}_{50}\right)$ determined for melittin was about 9-10 $\mu \mathrm{M}$. The antibacterial activity was further detected by the time-kill assay (Fig. 1b). At a concentration of $5 \mu \mathrm{M}$, melittin inhibited the growth of $X$. oryzae pv. oryzae slightly. However, when the concentration increased to $10 \mu \mathrm{M}$, the number of viable cells decreased greatly, indicating that the growth of $X$. oryzae pv. oryzae was significantly inhibited. After a $10 \mathrm{~h}$ incubation, the number of viable cells decreased to an almost undetectable level. The effect of melittin on the nucleic acid content was determined by DAPI staining and fluorescence observations (Fig. 1c, 1d). After treatment with $10 \mu \mathrm{M}$ melittin, the fluorescence densities of DNA and RNA were reduced significantly, compared with the PBS controls, indicating that the bacterial number decreased greatly or that nucleic acid synthesis was inhibited. All of the data showed that melittin had antibacterial activity against the $X$. oryzae pv. oryzae plant pathogen.

\section{Melittin had the ability to disrupt bacterial cell membrane integrity}

The effect of melittin on the membrane of $X$. oryzae pv. oryzae was detected using SEM (Fig. 2a). The untreated X. oryzae pv. oryzae displayed short rods, and a normal smooth and bright surface without any apparent cellular debris. After treatment with $10 \mu \mathrm{M}$ melittin, obvious cell surface disruption with wrinkles was observed. The bacterial cell membranes were heavily disrupted, which was evident from the formation of potholes on the surface, and more frequent debris, indicating that most of the serious structural changes were caused by melittin. TEM observations indicated that the untreated pathogens were completely filled, having intact bacterial walls and well-defined membranes (Fig. 2b). After treatment with $10 \mu \mathrm{M}$ melittin, structure changes were observed. There were trumpet-shaped gaps at the end of the bacteria, and there were the regions where the antimicrobial peptide effected the

A
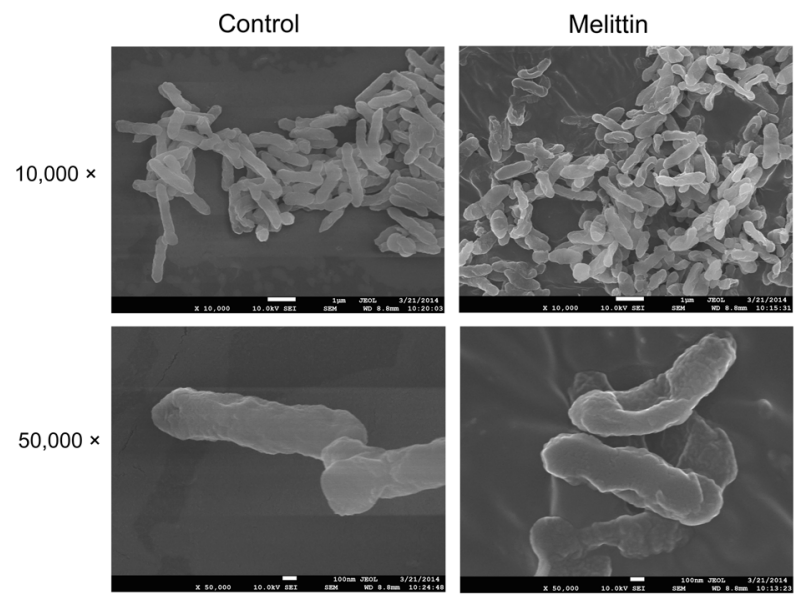

B
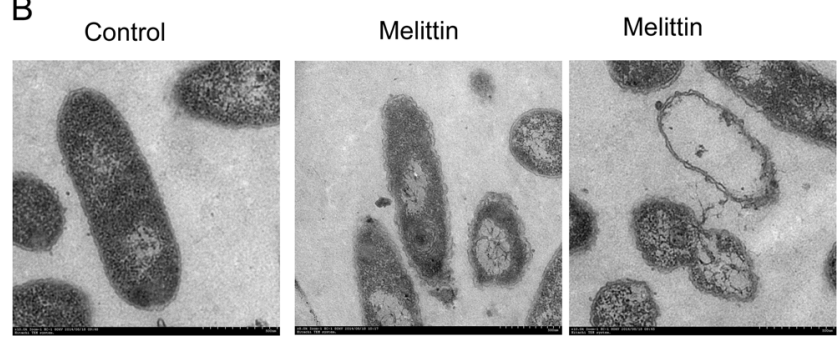

Fig. 2 Electron microscopy images of $X$. oryzae pv. oryzae treated with melittin. Bacteria were incubated with melittin for $30 \mathrm{~min}$ at $28^{\circ} \mathrm{C}$ and then observed by scanning electron microscopy (a) and transmission electron microscopy (b) 
formation of microtubule channels. There was leakage of the bacterial content as a result of wall disruption. The obvious release of the cytoplasmic contents through the membrane was also observed, and there were empty vesicles, which maintained bacterial cell appearance prior to their collapse.

\section{Melittin had the ability to penetrate the bacterial cell membrane}

FITC-labeled melittin, visualized using a confocal laser scanning microscope, was used to determine whether melittin had the ability to penetrate the bacterial cell membrane. As shown in Fig. 3a, FITC fluorescence accumulated in the cytoplasm of $X$. oryzae pv. oryzae after treatment with FITC-labeled melittin for $30 \mathrm{~min}$. Furthermore, FITC fluorescence was mainly amassed at the end of the rod shape. These results indicated that FITC-melittin may penetrate the cell membrane and be distributed in the cytoplasm.

The activity of T-ATPase was further detected to determine whether energy metabolism was affected by melittin. As shown in Fig. 3b, the melittin did not significantly suppress the T-ATPase activity compared with the control. Thus, melittin may have no effect on the energy metabolism of the cells.

\section{Melittin had binding activity to $X$. oryzae pv. oryzae DNA in vitro}

A gel retardation assay was conducted to determine whether melittin had DNA-binding activity. As shown in Fig. 4a, at a peptide/DNA weight ratio of 0.05 , almost all of the DNA remained at the origin. When the peptide/DNA weight ratio was increased to 0.5 , additional $X$. oryzae pv. oryzae genomic DNA was degraded, and a DNA fragment of 1200 bp was released from the genomic DNA. At peptide/DNA weight ratios of 1 and 2, similar results were observed. In particular, at the peptide/DNA weight ratio of 3, a complete retardation of the DNA was observed, indicating that the DNA was aggregated by melittin. Therefore, melittin had the ability to bind to genomic DNA in vitro and then degraded the genomic melittin DNA to 1000-2000-bp fragments.

Four DNA restriction enzymes with different sites were used to further identify the binding activity of melittin to DNA. As shown in Fig. 4b, after treatment with HindIII (A/AGCTT), KpnI (GGTAC/C), SacI (GAGCT/C), and EcoRI-HF (G/AATTC), X. oryzae pv. oryzae genomic DNA was cut into different-sized fragments, exhibited as smear patterns by gel electrophoresis. However, the smear fragments decreased after treatment with melittin. All of the data indicated that melittin could bind to genomic DNA in vitro.

\section{Melittin had binding activity to $X$. oryzae pv. oryzae RNA}

The RNA-binding ability of melittin was evaluated using gel retardation assays. At the peptide/RNA weight ratio of 1.2, the migration of RNA was suppressed by melittin. When the peptide/RNA weight ratio was increased to 3 , significant retardation was observed, indicating that melittin had the ability to bind RNA. After treatment with $10 \mu \mathrm{M}$ melittin for $5 \mathrm{~h}$, the total protein profile of $X$. oryzae pv. oryzae was decreased greatly, with the loss of some bands in the SDS-PAGE analysis (Fig. 5b). This result indicated that protein expression may be suppressed by melittin.

\section{Melittin prevention of $X$. oryzae pv. oryzae in rice}

Rice plants at the three- or four-leaf stage were used to establish a model of the rice bacterial leaf blight by injecting with the $X$. oryzae pv. oryzae pathogen. As shown in Fig. 6a, 6b, the development of disease symptoms was predominant in the bacterial blight disease model when compared with the noninjected plants. After treatment with melittin, the development of disease was controlled (Fig. 6c). The results from the lesion measurement experiment showed that very short lesions (average $1.38 \pm 0.28 \mathrm{~cm}$ ) were found in the melittin-treated group compared with the positive control group, which was susceptible to the pathogen and had long lesions (average $13.12 \pm 0.89 \mathrm{~cm})$. Hence, the melittin treatment is effective for the protection of rice from the $X$. oryzae pv. oryzae pathogen.

\section{Discussion}

Rice is the staple diet of more than three billion people, and the yield must double over the next 40 years if we are to sustain the nutritional needs of an ever-expanding global population (Skamnioti and Gurr 2009). However, rice is vulnerable to disease wherever it is grown and bacterial leaf blight of rice caused by $X$. oryzae pv. oryzae is one of the most destructive bacterial diseases worldwide. Che et al. (2011) reported that the Hpa-1-cecropin A (KLFKKIEKV)-melittin (KIFKKIEKKV-AVLKVLTTGL) hybrid peptide inhibited several bacteria and fungi, including $X$. oryzae pv. oryzae. However, whether melittin inhibits this plant pathogen is still unknown. In this study, we found that the antimicrobial peptide, melittin, showed antibacterial activity against the $X$. oryzae pv. oryzae plant pathogen. Many reports have indicated that melittin possesses broad antimicrobial activities in vitro. We tested the antimicrobial activity of melittin against several plant pathogen, including Ralstonia solanacearum, Magnaporthe grisea, Ustilaginoidea oryzae, Alternaria alternata (Fries) Keissler, Fusarium graminearum Sehw, and scab of cucurbits. The results showed that melittin had 
Fig. 3 Cellular uptake analyzed by confocal microscopic images. Bacteria were treated with FITC-melittin at a concentration of $10 \mu \mathrm{M}$ at $28^{\circ} \mathrm{C}$ for $30 \mathrm{~min}$ (a). The effect on energy metabolism was also assessed by determining the ATP consumption (b)

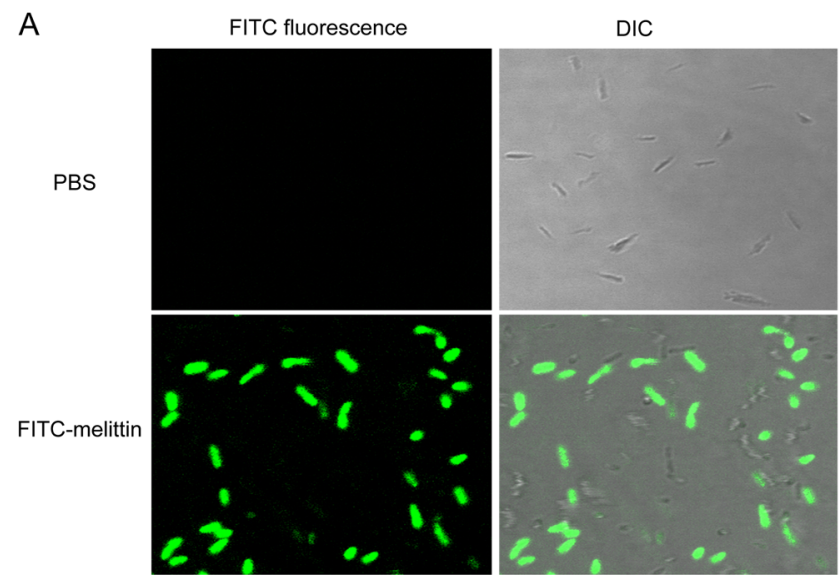

B

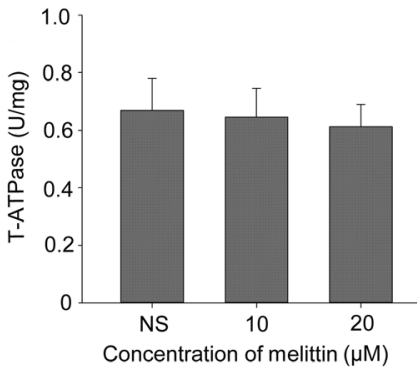

weak antimicrobial activities against these important plant pathogens (data not shown).

A better understanding of the melittin and $X$. oryzae pv. oryzae interactions will greatly help develop melittin use in rice plant protection. Previous investigations of the actions of melittin on cell membranes were conducted mainly using synthetic model membranes. They hypothesized that melittin disrupted membrane bilayers via a two-step "detergent-like" mechanism. The first step involves the electrostatic interaction of melittin with negatively charged lipid headgroups. After the concentration of melittin on the lipid surface reaches a critical concentration, melittin rearranges to form pore-like structures that disrupt the membrane bilayer (Lee et al. 2013). However, little research has been conducted using natural membranes of plant pathogens. In our study, FITC-labeled melittin had the binding ability to $X$. oryzae pv. oryzae, a Gram-negative plant pathogen, which may have resulted from electrostatic interactions. Melittin also had the ability to cause surface roughening and shrinking, and the formation of potholes, which indicated that the cell membrane structure was disrupted and that channels could be formed by melittin. Moreover, the wall disruption led to the leakage of bacterial contents, with empty vesicles remaining, and debris was also observed, indicating that melittin had the ability to kill cells through membrane-permeability/disrupting mechanism. This resulted in rapid cell death in the X. oryzae pv. oryzae pathogen. Melittin is a small linear peptide compound of 26 amino acids with a hydrophobic Nterminal region and a hydrophilic C-terminal region. Datiles reported that the ATPase activity of Escherichia coli was inhibited by melittin (Datiles et al. 2008). However, melittin had no effect on the energy metabolism of this plant pathogen, as indicated by the activity of the T-ATPase assay.

In addition to membrane-permeabilizing/disrupting properties, many AMPs also interact with intracellular targets or disrupt cellular processes. Our study together with other studies showed that melittin killed bacteria mainly by permeabilizing/disrupting the microbial cytoplasmic membrane (Lee et al. 2013). Very interestingly, using FITC labeling and confocal microscopy, we found that melittin not only bound the plasma membrane, but also entered cells. Thus, melittin used its membrane binding properties to kill bacteria by rapidly lysing the cells. At the same time, melittin also had the chance to enter the cells, which may have resulted from the disruption of the membrane. In eukaryotes, melittin has several mechanisms to kill yeast and cancer cells (Gajski and Garaj-Vrhovac 2013). Park and Lee (2010) speculated that melittin could more easily translocate the plasma membrane and then bind to intracellular molecules, which might trigger apoptosis in Candida albicans (Park and Lee 2010). In human leukemic U937 cells, melittin could induce Bcl-2- and caspase-3-dependent apoptosis through the downregulation of Akt phosphorylation (Moon et al. 2008).

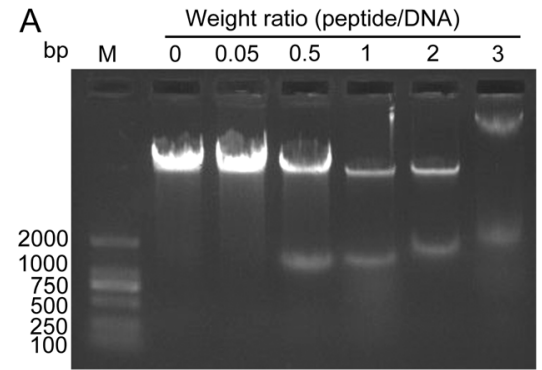

B

15000
8000
5000
3000
2000
1000

Fig. 4 The effect of melittin on the genomic DNA of X. oryzae pv. oryzae. A gel retardation assay was conducted after various amounts of peptides were incubated with $600 \mathrm{ng}$ of DNA for $1 \mathrm{~h}$. The weight ratios
(peptide:DNA) were $0.05,0.5,1,2$, and 3 (a). Effect of melittin on DNA restriction enzyme digestion by HindIII (E1), KpnI (E2), SacI (E3), and EcoRI-HF (E4). $M$ marker, $P$ peptide melittin (b) 

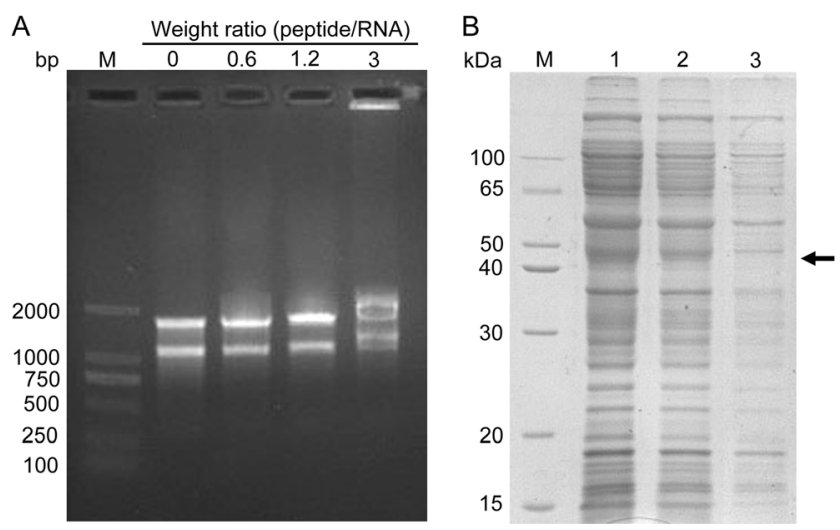

Fig. 5 The effect of melittin on RNA. A gel retardation analysis of the binding activity of melittin to RNA. Various amounts of melittin were incubated with $600 \mathrm{ng}$ of RNA for $1 \mathrm{~h}$, the weight ratios (peptide:RNA) were $0.6,1.2$, and 3 (a). SDS-PAGE analysis of the change of total proteins in bacteria. Lane 1, PBS treatment as a control; lane 2, $5 \mu \mathrm{M}$ melittin treatment for $5 \mathrm{~h}$; lane $3,10 \mu \mathrm{M}$ melittin treatment for $5 \mathrm{~h}$. The black arrows indicate lost protein bands (b)

The gel retardation assay showed that melittin strongly bound to DNA/RNA in vitro, suggesting the possibility of inhibition of intracellular functions via interference with DNA/RNA functions. The five cationic residues in melittin may enable electrostatic interactions with the negatively charged DNA. In addition to cationic residues, a leucine zipper motif, which is a typical DNA-binding domain with every seventh amino acid being leucine/isoleucine, was identified in melittin (Asthana et al. 2004). In fact, besides melittin, several other AMPs inhibit DNA synthesis by binding, including buforin IIB, indolicidin, and NKLP27, which are known to bind DNA, inhibit DNA synthesis, and induce the filamentation of bacteria (Hsu et al. 2005; Zhang et al. 2014). The inhibition of protein synthesis was also observed in our study, as observed in an SDS-PAGE analysis. We also found that the fluorescence density of nucleic acids were reduced significantly by melittin, which may be the result of the death of $X$. oryzae pv. oryzae or the inhibition of proliferation.
Finding an antibacterial activity for melittin in vitro experiments is not predictive of its capacity to protect the rice plant in vivo from $X$. oryzae pv. oryzae, because several host components could interfere with the AMP's activity (Montesinos and Bardaji 2008). Therefore, an inhibition assay was conducted to assess the prevention of infection in rice plants exposed to the $X$. oryzae pv. oryzae pathogen. Our data showed that melittin exhibited effective protection of rice against $X$. oryzae pv. oryzae. Chemical pesticides have been widely used in the past years and their effects on long-term environmental pollution, and carcinogenic effects on humans and other animals, limit their use (Daoubi et al. 2005). AMPs, as a control source with a potentially reduced negative environmental impact and a broad spectrum of activities, have attracted much attention in plant protection research (Morassutti et al. 2002). The quick kill effect of melittin, which is mainly caused by membrane disruption, makes it difficult for $X$. oryzae pv. oryzae to develop resistance to melittin. Although there are several problems for melittin, such as its high hemolysis, a lack of selectivity toxicity and high protease degradation, which limit the use of melittin as an antibacterial agent and anticancer agent to human (Asthana et al. 2004; Dempsey 1990; Oren and Shai 1997), application for plant protection might be possible. However, after treatment of rice with melittin, the plant height, tillering ability, and the leaf color and shape were identical to the PBS control. Furthermore, no lesion mimic were observed in our experiment. All these showed that the rice plants were healthy after the melittin treatment, indicating a lack of undesirable toxic effects on rice. This may result from the differences in cell structure between mammal cells and plant cells. Therefore, melittin represents a promising candidate for further development to protect rice from bacterial leaf blight. Expression of several AMP coding genes in plants has been used to enhance their resistance to bacterial and fungal pathogens (Carmona et al. 1993; Che et al. 2011). Additionally, the transgenic plants showed considerably greater resistance to certain
Fig. 6 Plant disease reduction by melittin. Normal rice leaves (a). Rice leaves infected with $X$. oryzae pv. oryzae (b). Application of melittin to prevent leaf blight of rice caused by $X$. oryzae pv. oryzae (c). The lesions were measured 7 days after inoculation
A

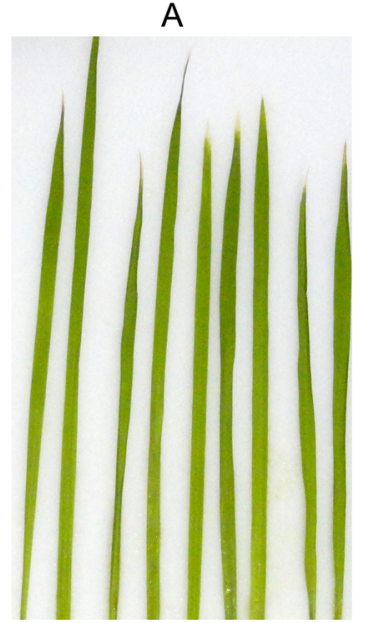

B

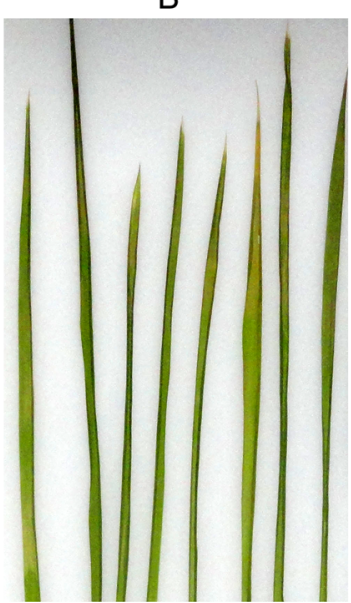

C

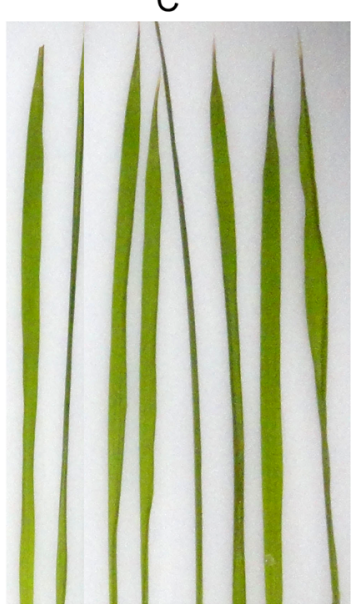


pathogens than wild-type plants (Jan et al. 2010; Lakshman et al. 2013; Nadal et al. 2012). Thus, in addition to being used directly as an agricultural pesticide, melittin may be a candidate in developing transgenic rice with resistance to bacterial leaf blight. However, developing less toxic and more stable compounds requires further research. Structural modifications to reduce the hemolytic activity have been conducted (Pandey et al. 2010). Developing more effective and less toxic derivatives of melittin to protect rice from $X$. oryzae pv. oryzae is urgently needed.

Acknowledgments This work was financially supported by a grant of the National Natural Science Foundation of China (Grant No. 30900743 , 81573337), the Natural Science Foundation of Jiangsu Province of China (Grant No. BK2011368, BK20141446), and the Priority Academic Program Development of Jiangsu Higher Education Institutions (PAPD).

\section{Compliance with ethical standards}

Conflict of interest The authors have declared no conflict of interest.

Ethical statement This article does not contain any studies with human participants or animals performed by any of the authors.

Open Access This article is distributed under the terms of the Creative Commons Attribution 4.0 International License (http:// creativecommons.org/licenses/by/4.0/), which permits unrestricted use, distribution, and reproduction in any medium, provided you give appropriate credit to the original author(s) and the source, provide a link to the Creative Commons license, and indicate if changes were made.

\section{References}

Alan AR, Earle ED (2002) Sensitivity of bacterial and fungal plant pathogens to the lytic peptides, MSI-99, magainin II, and cecropin B. Mol Plant-Microbe Interact 15:701-708

Al-Ani I, Zimmermann S, Reichling J, Wink M (2015) Pharmacological synergism of bee venom and melittin with antibiotics and plant secondary metabolites against multi-drug resistant microbial pathogens. Phytomedicine 22:245-255

Alia O, Laila M, Antonious A (2013) Antimicrobial effect of melittin isolated from Syrian honeybee (Apis mellifera) venom and its wound healing potential. Int J Pharm Sci Rev Res 21:318-324

Asthana N, Yadav SP, Ghosh JK (2004) Dissection of antibacterial and toxic activity of melittin: a leucine zipper motif plays a crucial role in determining its hemolytic activity but not antibacterial activity. J Biol Chem 279:55042-55050

Basso A, Onasanya A, Issaka S, Sido AY, Haougui A, Adam T, Sere Y, Saadou M (2011) Bacterial leaf blight of rice in Niger: pathological diversity of isolates collected on irrigated lands. J Applied Biosci 38: 2551-2563

Burdman S, Shen Y, Lee SW, Xue Q, Ronald P (2004) RaxH/RaxR: a two-component regulatory system in Xanthomonas oryzae pv. oryzae required for AvrXa21 activity. Mol Plant-Microbe Interact $17: 602-612$

Carmona MJ, Molina A, Fernández JA, López-Fando JJ, García-Olmedo F (1993) Expression of the $\alpha$-thionin gene from barley in tobacco confers enhanced resistance to bacterial pathogens. Plant J 3:457462

Che YZ, Li YR, Zou HS, Zou LF, Zhang B, Chen GY (2011) A novel antimicrobial protein for plant protection consisting of a Xanthomonas oryzae harpin and active domains of cecropin A and melittin. Microb Biotechnol 4:777-793

Coca M, Penas G, Gomez J, Campo S, Bortolotti C, Messeguer J, Segundo BS (2006) Enhanced resistance to the rice blast fungus Magnaporthe grisea conferred by expression of a cecropin A gene in transgenic rice. Planta 223:392-406

Daoubi M, Hernández-Galán R, Benharref A, Collado IG (2005) Screening study of lead compounds for natural product-based fungicides: antifungal activity and biotransformation of $6 \alpha, 7 \alpha$-dihydroxy- $\beta$-himachalene by Botrytis cinerea. J Agric Food Chem 53: $6673-6677$

Datiles MJ, Johnson EA, McCarty RE (2008) Inhibition of the ATPase activity of the catalytic portion of ATP synthases by cationic amphiphiles. Biochim Biophys Acta 1777:362-368

Dempsey CE (1990) The actions of melittin on membranes. Biochim Biophys Acta 1031:143-161

Falco A, Barrajón-Catalán E, Menéndez-Gutiérrez MP, Coll J, Micol V, Estepa A (2013) Melittin-loaded immunoliposomes against viral surface proteins, a new approach to antiviral therapy. Antivir Res 97:218-221

Gajski G, Garaj-Vrhovac V (2013) Melittin: a lytic peptide with anticancer properties. Environ Toxicol Pharmacol 36:697-705

Hsu CH, Chen C, Jou ML, Lee AY, Lin YC, Yu YP, Huang WT, Wu SH (2005) Structural and DNA-binding studies on the bovine antimicrobial peptide, indolicidin: evidence for multiple conformations involved in binding to membranes and DNA. Nucleic Acids Res 33:4053-4064

Jan PS, Huang HY, Chen HM (2010) Expression of a synthesized gene encoding cationic peptide cecropin B in transgenic tomato plants protects against bacterial diseases. Appl Environ Microbiol 76: $769-775$

Lakshman DK, Natarajan S, Mandal S, Mitra A (2013) Lactoferrinderived resistance against plant pathogens in transgenic plants. J Agric Food Chem 61:11730-11735

Lee BM, Park YJ, Park DS, Kang HW, Kim JG, Song ES, Park IC, Yoon UH, Hahn JH, Koo BS, Lee GB, Kim H, Park HS, Yoon KO, Kim JH, Jung CH, Koh NH, Seo JS, Go SJ (2005) The genome sequence of Xanthomonas oryzae pathovar oryzae KACC10331, the bacterial blight pathogen of rice. Nucleic Acids Res 33:577-586

Lee MT, Sun TL, Hung WC, Huang HW (2013) Process of inducing pores in membranes by melittin. Proc Natl Acad Sci U S A 110: $14243-14248$

Lee TH, Hall KN, Aguilar MI (2016) Antimicrobial peptide structure and mechanism of action: a focus on the role of membrane structure. Curr Top Med Chem 16:25-39

Liu H, Han Y, Fu H, Liu M, Wu J, Chen X, Zhang S, Chen Y (2013) Construction and expression of sTRAIL-melittin combining enhanced anticancer activity with antibacterial activity in Escherichia coli. Appl Microbiol Biotechnol 97:2877-2884

Ma JF, Goto S, Tamai K, Ichii M (2001) Role of root hairs and lateral roots in silicon uptake by rice. Plant Physiol 127:1773-1780

Montesinos E (2007) Antimicrobial peptides and plant disease control. FEMS Microbiol Lett 270:1-11

Montesinos E, Bardaji E (2008) Synthetic antimicrobial peptides as agricultural pesticides for plant-disease control. Chem Biodivers 5: $1225-1237$

Moon DO, Park SY, Choi YH, Kim ND, Lee C, Kim GY (2008) Melittin induces Bcl-2 and caspase-3-dependent apoptosis through downregulation of Akt phosphorylation in human leukemic U937 cells. Toxicon 51:112-120

Morassutti C, De Amicis F, Skerlavaj B, Zanetti M, Marchetti S (2002) Production of a recombinant antimicrobial peptide in transgenic 
plants using a modified VMA intein expression system. FEBS Lett 519:141-146

Nadal A, Montero M, Company N, Badosa E, Messeguer J, Montesinos L, Montesinos E, Pla M (2012) Constitutive expression of transgenes encoding derivatives of the synthetic antimicrobial peptide BP100: impact on rice host plant fitness. BMC Plant Biol 12: 159

Oren Z, Shai Y (1997) Selective lysis of bacteria but not mammalian cells by diastereomers of melittin: structure-function study. Biochemistry 36:1826-1835

Pandey BK, Ahmad A, Asthana N, Azmi S, Srivastava RM, Srivastava S, Verma R, Vishwakarma AL, Ghosh JK (2010) Cell-selective lysis by novel analogues of melittin against human red blood cells and Escherichia coli. Biochemistry 49:7920-7929

Park C, Lee DG (2010) Melittin induces apoptotic features in Candida albicans. Biochem Biophys Res Commun 394:170-172

Park CB, Kim HS, Kim SC (1998) Mechanism of action of the antimicrobial peptide buforin II: buforin II kills microorganisms by penetrating the cell membrane and inhibiting cellular functions. Biochem Biophys Res Commun 244:253-257

Skamnioti P, Gurr SJ (2009) Against the grain: safeguarding rice from rice blast disease. Trends Biotechnol 27:141-150

Tripathi JK, Pal S, Awasthi B, Kumar A, Tandon A, Mitra K, Chattopadhyay N, Ghosh JK (2015) Variants of self-assembling peptide, KLD-12 that show both rapid fracture healing and antimicrobial properties. Biomat 56:92-103

Zeitler B, Herrera Diaz A, Dangel A, Thellmann M, Meyer H, Sattler M, Lindermayr C (2013) De-novo design of antimicrobial peptides for plant protection. PLoS one 8:e71687

Zhang LJ, Gallo RL (2016) Antimicrobial peptides. Curr Biol 26(1):R14 R19

Zhang M, Li MF, Sun L (2014) NKLP27: a teleost NK-lysin peptide that modulates immune response, induces degradation of bacterial DNA, and inhibits bacterial and viral infection. PLoS one 9:e106543

Zhu XF, Xu Y, Peng D, Zhang Y, Huang TT, Wang JX, Zhou MG (2013) Detection and characterization of bismerthiazol-resistance of Xanthomonas oryzae pv. oryzae. Crop Prot 47:24-29 